OPEN ACCESS

Edited by:

Hongyue Dang,

Xiamen University, China

Reviewed by:

Ramprasad E. V. V.,

University of Hyderabad, India

Isao Yumoto,

National Institute of Advanced

Industrial Science and Technology

(AIST), Japan

${ }^{*}$ Correspondence:

Zong-Jun Du

duzongjun@sdu.edu.cn

Specialty section:

This article was submitted to

Aquatic Microbiology,

a section of the journal

Frontiers in Microbiology

Received: 23 September 2019

Accepted: 25 March 2020

Published: 22 April 2020

Citation:

Wang S, Mu D and Du Z-J (2020)

Persicimonas caeni gen. nov., sp.

nov., the Representative of a Novel Wide-Ranging Predatory Taxon

in Bradymonadales.

Front. Microbiol. 11:698.

doi: 10.3389/fmicb.2020.00698

\section{Persicimonas caeni gen. nov., sp. nov., the Representative of a Novel Wide-Ranging Predatory Taxon in Bradymonadales}

\author{
Shuo Wang ${ }^{1}$, Dashuai $\mathrm{Mu}^{1,2}$ and Zong-Jun Dü,2* \\ ${ }^{1}$ Marine College, Shandong University, Weihai, China, ${ }^{2}$ State Key Laboratory of Microbial Technology, Shandong University, \\ Qingdao, China
}

A novel bacterial strain, designated $\mathrm{YN} 101^{\top}$, was isolated from a marine solar saltern in the coast of Weihai, Shandong Province, China. Strain YN101 ${ }^{\top}$ was Gram-stain negative, facultatively anaerobic, oxidase and catalase negative bacterium with the ability to prey on other microbes. A cross-streaking culture method was utilized to

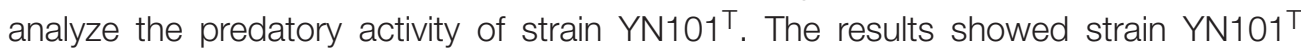
could prey on various bacteria, either Gram-stain negative or Gram-stain positive. According to the predatory assays, different species in the same genus may behave

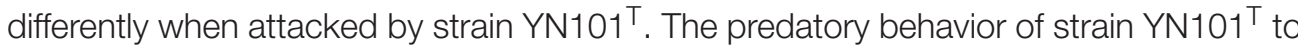
four typical species was analyzed, and furthermore, predation to Algoriphagus marinus am $2^{\top}$ were quantitatively studied by fluorogenic quantitative PCR, and the gene copies decreased over two magnitudes. Phylogenetic analysis based on 16S rRNA gene

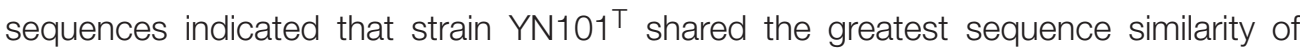
93.9\% to Bradymonas sediminis $\mathrm{FA} 350^{\top}$. The complete genome sequence of strain YN101 ${ }^{\top}$ was $8,047,306$ bp in size and the genomic DNA G + C content was 63.8 mol\%. The digital DNA-DNA hybridization $(\mathrm{dDDH})$ values and average nucleotide identity (ANI)

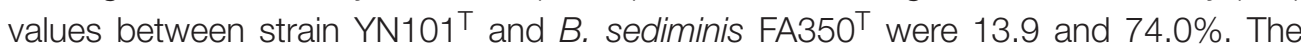
genetic features showed that the biosynthesis of many important compounds was

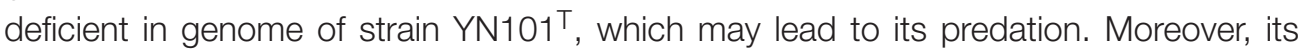
genome encoded many genes affiliated with type IV pili, secretion system, membrane proteins and transduction proteins. Similar with myxobacteria and Bdellovibrio and like organisms (BALOs), these genes should play important roles in motility, adhesion or virulence to attack prey cells during predation. The predominant polar lipid profile

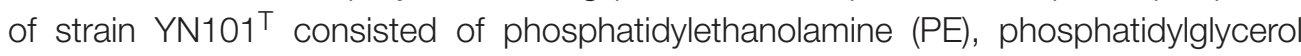
(PG), diphosphatidylglycerol (DPG), and one unidentified aminophospholipid (APL). The

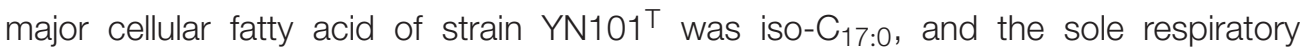


quinone was MK-7. Based on the chemotaxonomic, physiological and biochemical

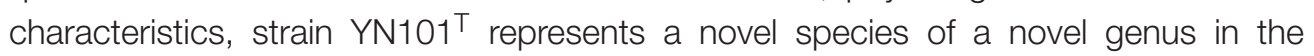
family Bradymonadaceae, for which the name Persicimonas caeni gen. nov., sp. nov. is proposed. The type strain is $\mathrm{YN}_{101}{ }^{\top}\left(=\mathrm{KCTC} 72083^{\top}=\right.$ MCCC $\left.1 \mathrm{H00374}{ }^{\top}\right)$.

Keywords: Bradymonadales, Bradymonadaceae, 16S rRNA gene, phylogenetic analysis, predatory bacteria, genomic analysis

\section{INTRODUCTION}

As of 2019, there are three valid published species separated into two genera in the order Bradymonadales, including Bradymonas sediminis $\mathrm{FA} 350^{\mathrm{T}}$ (Wang et al., 2015), Lujinxingia litoralis $\mathrm{B} 210^{\mathrm{T}}$ and Lujinxingia sediminis $\mathrm{SEH} 01^{\mathrm{T}}$ (Guo et al., 2019). B. sediminis FA $350^{\mathrm{T}}$ is the representative of the type genus of the type family. However, with developments in metagenome and 16S rRNA gene high-throughput sequencing technologies, more previously uncultured members of Bradymonadales have been discovered (Cheng et al., 2018; Bachran et al., 2019).

Members of the order Bradymonadales have numerous common properties, including low growth rate and lawn rather than colony formation on plates, etc. Furthermore, they all prey on other bacteria. As a new predatory order in Deltaproteobacteria, Bradymonadales were considered facultative predators according to our previous studies (Wang et al., 2019). Bacterial predators are artificially divided in two groups: facultative and obligate predators (Pérez et al., 2016). Facultative predators are mainly represented by myxobacteria, which can prey on bacteria or utilize other nutrients and substances from the environment. Bdellovibrio bacteriovorus is one representative of the obligate predators, which belongs to class Oligoflexia (Dashiff et al., 2011; Soo et al., 2015). For both forms of predation, hunting strategies can be categorized into two general types: epibiotic predation and direct invasion or penetration of the periplasm (Pérez et al., 2016). During the attack phase of the epibiotic predator, genes implicated in chemotaxis and flagellum biosynthesis were highly expressed, whereas during the attachment phase, genes involved in protein secretion and housekeeping genes were dramatically upregulated (Pérez et al., 2016). Bdellovibrio exovorus are highly motile cells during the extracellular attack phase, which swim using flagella to encounter their prey (Sockett, 2009; Rotem et al., 2015). During the growth phase, the predator irreversibly attaches to a Gram-stain negative bacterium and penetrates the periplasmic space, where it grows, replicates and kills the prey cell (Pérez et al., 2016). Almost all previously reported bacterial predation occurs in groups, including the two aforementioned types. However, the lysed cells after group attack benefit both the predator secreting cells and the non-secreting cells. Cells of

Abbreviations: dDDH, digital DNA-DNA hybridization; GGDC, genome-togenome distance; HPLC, High Performance Liquid Chromatography; KCTC, Korean Collection for Type Cultures; KEGG, Kyoto Encyclopedia of Genes and Genomes; MA, Marine agar 2216; MB, Marine broth 2216; MCCC, Marine Culture Collection of China; MEGA, Molecular Evolutionary Genetics Analysis; MIDI, Microbial Identification System; PG, peptidoglycan; RAST, Rapid Annotation using Subsystem Technology; TLC, Thin layer chromatography; UBCG, Up-todate bacterial core gene.
Myxococcus xanthus, a social bacterium predator, move in search of prey in a coordinated manner, forming dynamic multicellular groups referred to as swarms (Muñoz-Dorado et al., 2016), and type IV pili are associated with this strategy (Yoshikawa et al., 2008). Bacterial predation is thus related to different systems of motility.

Studies on B. sediminis FA350 ${ }^{\mathrm{T}}$ have described its predation strategy of cooperative attack. Genomic analyses showed cells encoded with genes affiliated with type IV pili, which allow cells to swiftly glide to prey during predation (Wang et al., 2019). B. sediminis $\mathrm{FA} 350^{\mathrm{T}}$ are able to prey on a wide range of different types of bacteria, with some presently unknown selection rules. Results of phenotypic tests and plate counting demonstrated the predation of B. sediminis FA350 ${ }^{\mathrm{T}}$, however, quantification of the predation over different time periods with mixed cultures remained elusive. Here, we introduce type strain $\mathrm{YN}_{101}{ }^{\mathrm{T}}$, a novel predatory taxon of Bradymonadales. Predation differences between strain $\mathrm{YN}_{101}{ }^{\mathrm{T}}$ and B. sediminis $\mathrm{FA} 350^{\mathrm{T}}$ were studied systematically. As the representatives of predatory groups in Deltaproteobacteria, Myxococcus xanthus DK1622 $2^{\mathrm{T}}$ was chosen as related strain. Two genomes of Bdellovibrio were also analyzed compared with strain $\mathrm{YN}_{101}{ }^{\mathrm{T}}$. Study on this novel species will further expand the membership of Bradymonadales, a new predatory bacterial group, which is of great significance in the exploration of microbial resources. Bradymonadales distributes widely in marine environment and may play important roles in the composition of marine microbial community and the global biochemical cycle. Descriptions on metabolic features during predation according to comparative genomic analyses are also important for deep insights into predatory mechanism. Therefore, studies on strain $\mathrm{YN} 101^{\mathrm{T}}$ will be of great significance in many aspects.

\section{MATERIALS AND METHODS}

\section{Bacteria Strains}

Strain $\mathrm{YN} 101^{\mathrm{T}}$ was isolated from a sediment sample collected from a marine solar saltern $\left(122^{\circ} 14^{\prime} \mathrm{E}, 36^{\circ} 54^{\prime} \mathrm{N}\right)$ in Weihai, China. A $100 \mu \mathrm{L}$ aliquot of diluted sample was spread on marine agar $2216(\mathrm{MA} ; \mathrm{BD})$ using the standard dilution plating technique to obtain pure cultures. Plates were incubated at $30^{\circ} \mathrm{C}$ for more than 30 days, and strain $\mathrm{YN}_{101}{ }^{\mathrm{T}}$ was isolated and stored at $-80^{\circ} \mathrm{C}$ in sterile $15 \%(\mathrm{v} / \mathrm{v})$ glycerol supplemented with $1 \%$ (v/v) $\mathrm{NaCl}$. B. sediminis FA350 ${ }^{\mathrm{T}}$ isolated by our laboratory (Wang et al., 2015) was used as the related strain for phenotypic and genetic analyses. 


\section{S rRNA Gene Sequence Analyses}

The 16S rRNA gene of strain $\mathrm{YN}_{101}{ }^{\mathrm{T}}$ was amplified from the genomic DNA by PCR with the universal primers $27 \mathrm{~F}$ and $1492 \mathrm{R}$ (Liu et al., 2014). PCR products were purified using a PCR product purification kit (Takara Bio Inc., Kusatsu, Japan), then ligated to the pMD18-T vector (Takara Bio Inc.) according to the manufacturer's instructions. Sequencing was performed by Ruibiotech Co. Ltd (Qingdao, China) using universal primers M13-R and M13-F (Han et al., 2017a). Phylogenetic trees were built by neighbor-joining, maximum-likelihood, and maximumparsimony methods using MEGA 7.0 software according to the 16S rRNA gene sequences (Felsenstein, 1981; Saitou and Nei, 1987; Kannan and Wheeler, 2012; Kumar et al., 2016). Genetic distances were calculated using the Kimura two-parameter model (Kimura, 1980). The BLAST algorithm was used to search for similar sequences ${ }^{1}$. The EzTaxon-e server ${ }^{2}$ was used to acquire sequence similarity values (Kim et al., 2012).

\section{Morphological Observations and Physiological Tests}

The effects of different growth temperatures were tested on incubations at $4,8,15,20,25,28,30,33,37,40,45,50$, and $55^{\circ} \mathrm{C}$ on modified MA until growth was indicated by visible lawn (no obvious colonies formed, about end-logarithmic growth period). Growth conditions were recorded every $12 \mathrm{~h}$. Modified MA consisted of distilled water with the following additions (all $\mathrm{g} \mathrm{L}^{-1}$ ): sea salt (Sigma-Aldrich, St. Louis, MO, United Stated), 30 ; yeast extract, 1 ; peptone, 5 ; sodium pyruvate, 0.1 ; and agar, 18. The $\mathrm{pH}$ was adjusted to 7.5. The effects on growth induced by $\mathrm{pH}$ were tested by altering the $\mathrm{pH}$ of modified $\mathrm{MB}$ without agar using various buffers: MES ( $\mathrm{pH} 5.5$ and 6.0), PIPES ( $\mathrm{pH}$ 6.5 and 7.0), HEPES (pH 7.5 and 8.0), Tricine ( $\mathrm{pH} 8.5$ ), and CAPSO (pH 9.0 and 9.5) at concentrations of $20 \mathrm{mM}$ (Sangon Biotech Co., Ltd., Shanghai, China). The $\mathrm{pH}$ of the medium was adjusted by adding $1 \mathrm{M} \mathrm{HCl}$ or $\mathrm{NaOH}$ before autoclaving and $\mathrm{OD}_{600}$ values of the culture were measured after incubation. The growth under different $\mathrm{NaCl}$ concentrations from 0 to $12 \%$ $\mathrm{NaCl}$ at $1 \%$ intervals was assessed using modified MA without sea salt, in which purified water was substituted for artificial seawater $\left(0.32 \% \mathrm{MgSO}_{4}, 0.12 \% \mathrm{CaCl}_{2}, 0.07 \% \mathrm{KCl}\right.$, and $0.02 \%$ $\mathrm{NaHCO}_{3}$, all in w/v).

The morphological and physiological features of strain $\mathrm{YN} 101^{\mathrm{T}}$ in end-logarithmic growth period were examined after incubation at $37^{\circ} \mathrm{C}$. Motility was examined using the hangingdrop method and gliding on modified MB supplemented with 0.3\% agar (Bernardet et al., 2002). A transmission electron microscope (JEM-1200EX; JEOL Ltd., Tokyo, Japan) was used to observe cell size and morphology. Antibiotic sensitivity was assessed as described by the Clinical and Laboratory Standards Institute (CLSI, 2019): a cell suspension (McFarland standard 0.5) was swabbed over the surface of modified MA plates to create a uniform lawn before aseptic placement of antibiotic disks onto the agar surface.

${ }^{1}$ https://blast.ncbi.nlm.nih.gov/Blast.cgi

${ }^{2} \mathrm{http} / / /$ www.ezbiocloud.net
Catalase activity was detected by bubble production after the addition of $3 \%(\mathrm{v} / \mathrm{v}) \mathrm{H}_{2} \mathrm{O}_{2}$, and oxidase activity was determined using reagent kit (Diamond Bio Scientific LLC). Anaerobic growth was determined by inoculation on modified MA supplemented with $0.1 \%(\mathrm{w} / \mathrm{v})$ sodium pyruvate, with or without $0.5 \%(\mathrm{w} / \mathrm{v})$ sulfate or $0.1 \%(\mathrm{w} / \mathrm{v})$ nitrate in an anaerobic jar. Modified MB supplemented with $0.1 \%(\mathrm{w} / \mathrm{v})$ nitrate was used for the nitrate-reducing test; inoculated and uninoculated cultures in test tubes under aerobic and anaerobic conditions at $37^{\circ} \mathrm{C}$ served as treatment and control groups, respectively. Hydrolysis of starch, cellulose, lipids and alginate was tested on modified MA supplemented with $0.2 \%(\mathrm{w} / \mathrm{v})$ soluble starch, $0.5 \%$ (w/v) CM-cellulose, 1\% (w/v) Tweens 20, 40, 60, 80, and 2\% (w/v) sodium alginate (Cowan and Steel, 1965).

\section{Chemotaxonomic Characteristics}

Respiratory quinones were analyzed by log-phase cells under optimal physiological conditions. Extraction from $300 \mathrm{mg}$ of freeze-dried cell material was separated into different classes by TLC on silica gel (Tindall B., 1990; Tindall B.J., 1990). In accordance with the spots on the silica gel plate, the effective components were removed from the plate and analyzed further by using reverse-phase HPLC (VP-ODS, $250 \times 4.6 \mathrm{~mm}$; Shimadzu, LC-20A), then eluted with a mixture of acetonitrile and isopropanol $(3: 2, \mathrm{v} / \mathrm{v})$ at a flow rate of $1 \mathrm{~mL} \mathrm{~min}^{-1}$.

Fatty acid composition was determined by first incubating cells of strain $\mathrm{YN} 101^{\mathrm{T}}$ on modified $\mathrm{MB}$ at $37^{\circ} \mathrm{C}$ to reach the exponential stage of growth, according to the four quadrants streak method. Fatty acids were saponified, methylated and extracted using the standard protocol of the Sherlock microbial identification system version 6.1 (MIDI Inc., Newark, United States) equipped with an Agilent model $6890 \mathrm{~N}$ gas chromatograph (Agilent Technologies, Santa Clara, CA, United States). Peaks were automatically integrated and fatty acid names and percentages were calculated using MIS standard software with the TSBA40 database (MIDI Inc.).

Cells cultured in modified $\mathrm{MB}$ at $37^{\circ} \mathrm{C}$ were used to determine the polar lipids using two-dimensional silica gel thin-layer chromatography (TLC, 1.05554.0001; Merck, Kenilworth, United States) (Xu et al., 2007). Total lipid materials were detected using molybdatophosphoric acid and specific functional groups were detected using spray staining reagents (SigmaAldrich) on four separate TLC plates: phosphomolybdic acid solution (total lipids), molybdenum blue solution (phosphates), $\alpha$-naphthol sulfuric solution (carbohydrates) and ninhydrin (amines).

Tests for other physiological and biochemical characteristics were determined using API 20E and API ZYM test strips (bioMérieux Inc., Marcy-l'Étoile, France), according to the manufacturer's instructions, apart from the suspension being prepared with sterilized $3 \%(\mathrm{w} / \mathrm{v})$ sea salt (Sigma-Aldrich) solution. The strain was further tested for oxidization ability of various carbon sources using the GEN III Microplate according to the manufacturer's instructions (Biolog Inc., Hayward, CA, United States). The ability to produce acid from carbohydrates was tested using the API 50CHB fermentation kit (bioMérieux Inc.) according to the manufacturer's instructions. The salinity of 
the supplementary medium of both kits was adjusted to 3\% with sea salt (Sigma-Aldrich). The API strips and Biolog results were recorded every $24 \mathrm{~h}$ after incubation at $37^{\circ} \mathrm{C}$ until all reactions were steady. All API and Biolog tests were performed in duplicate under identical conditions.

\section{Predation Tests}

Cross-streaking incubation tests (Supplementary Figure S1B) were performed to demonstrate the predation of strain $\mathrm{YN}_{101}{ }^{\mathrm{T}}$ and B. sediminis FA350 ${ }^{\mathrm{T}}$. A suspension (McFarland standard 5.0) of predatory bacteria was prepared and inoculated on MA in the first direction, followed by the suspension of prey bacteria (McFarland standard 5.0) inoculated in the second direction across the first inoculation line. The plate was then incubated until the growth of both bacteria was indicated by visible lawn.

To further detect the predation of Bradymonadales, a cocultured system allowing predation was built. Concentrated suspensions (McFarland standard 5.0) of strain $\mathrm{YN}_{101}{ }^{\mathrm{T}}$ (predator) and Algoriphagus marinus am $2^{\mathrm{T}}$ (prey) in logarithmic phase were co-incubated (1:1 volume ratio) onto the micropore filtration membrane $(50 \mathrm{~mm}, 0.2 \mu \mathrm{m})$ attached to the MA medium at $33^{\circ} \mathrm{C}$ (Han et al., 2017b). Mono-cultured predator and prey were incubated as control groups. Genomic DNA was extracted from the inoculated cultures after 0,68 , and 120 h. Primers and TaqMan probes (modified with FAM/BHQ1) based on specific gene sequences for each species were designed using the PrimerQuest Tool ${ }^{3}$. Changes in biomass of each species in the co-cultured system were quantified by fluorescent quantitative realtime-PCR. Results were demonstrated as line graphs using Origin 8.0 Trial software ${ }^{4}$. The PCR and reaction system program, as well as the sequences of specific genes, corresponding primers and TaqMan probes are available in Supplementary File S1 in the online Supplementary Material.

\section{Whole Genome Sequencing and Analyses}

The genomic DNA of strain $\mathrm{YN} 101^{\mathrm{T}}$ was extracted using a DNA extraction kit (Takara Bio) according to the manufacturer's instructions. The complete genome of strain $\mathrm{YN} 101^{\mathrm{T}}$ was sequenced by Novogene Biotechnology Co. (Beijing, China) using the Illumina PE150 platform (Illumina, San Diego, CA, United States). Assembly of the raw sequencing data was performed using SOAPdenovo version $2.04^{5}$, SPAdes and ABySS, and was finally integrated by CISA. The assembly results were optimized with GapCloser Version 1.12, and fragments below 500 bp were filtered out. A phylogenomic tree was constructed based on 92 up-to-date bacterial core gene sequences of strain $\mathrm{YN} 101^{\mathrm{T}}$ and type strains of related taxa using the UBCG tools ${ }^{6}$ ( $\mathrm{Na}$ et al., 2018) with a maximumlikelihood algorithm (Felsenstein, 1981). The digital DNADNA hybridization $(\mathrm{dDDH})$ values between strain $\mathrm{YN}_{101}{ }^{\mathrm{T}}$

\footnotetext{
${ }^{3}$ sg.idtdna.com/PrimerQuest

${ }^{4}$ www.originlab.com

${ }^{5}$ https://github.com/aquaskyline/SOAPdenovo2

${ }^{6}$ www.ezbiocloud.net/tools/ubcg
}

and the related strains were calculated using the Genome-toGenome distance calculator (GGDC) ${ }^{7}$. Evaluations and statistical analyses were undertaken to perform genetic predictions. Comparative genetic analyses were performed utilizing RAST (Rapid Annotation using Subsystem Technology ${ }^{8}$ ) and KEGG (Kyoto Encyclopedia of Genes and Genomes) ${ }^{9}$ software. The analyses were presented using Heml 1.0 heatmap illustration software ${ }^{10}$.

\section{RESULTS}

\section{S rRNA Gene Sequence Analyses}

A nearly complete $16 \mathrm{~S}$ rRNA gene sequence of strain $\mathrm{YN}_{101}{ }^{\mathrm{T}}$ obtained by amplification (1458 bp) was included in the 16S rRNA gene sequence assembled from genomic sequences (1536 bp). All three 16S rDNA sequences from the genome sequence were of the same lengths and could be identified as complete sequences in accordance with the NCBI gene database ${ }^{11}$. Strain $\mathrm{YN}_{101}{ }^{\mathrm{T}}$ shared the highest level of similarity with B. sediminis $\mathrm{FA}_{350^{\mathrm{T}}}(93.9 \%)$, followed by Pelobacter propionicus DSM $2379^{\mathrm{T}}$ (85.0\%), Desulfuromonas svalbardensis $112^{\mathrm{T}}(85.0 \%)$ and Geobacter pickeringii $\mathrm{G} 13^{\mathrm{T}}(85.0 \%)$, all of which belong to the order Desulfuromonadales. On the basis of phylogenetic analysis using the neighbor-joining algorithm, strain $\mathrm{YN}_{101}{ }^{\mathrm{T}}$ formed a phylogenetic cluster with B. sediminis FA $350^{\mathrm{T}}$ at the $100 \%$ bootstrap confidence level, forming an evident cluster group distinctly separated from genus Lujinxingia. The taxonomic status was also demonstrated by maximumlikelihood and maximum-parsimony trees (Figure 1).

\section{Morphological Observations and Physiological Tests}

Optimal growth of strain $\mathrm{YN}_{101}{ }^{\mathrm{T}}$ occurred with $3-4 \% \mathrm{NaCl}$ (range $1-10 \%, \mathrm{w} / \mathrm{v}$ ), at $37^{\circ} \mathrm{C}\left(\right.$ range $15-50^{\circ} \mathrm{C}$ ) and $\mathrm{pH} 8.0-8.5$ (range 6.5-9.0). However, B. sediminis $\mathrm{FA} 350^{\mathrm{T}}$ grow at $33^{\circ} \mathrm{C}$ $\left(20-37^{\circ} \mathrm{C}\right)$ optimally. Few apparent colonies formed after 6 days (logarithmic phase) of incubation at $37^{\circ} \mathrm{C}$, and the colonies were circular or irregular, pink-colored, about $1 \mathrm{~mm}$ diameter, and with entire and transparent edges. Electron micrograph images showed rod-shaped cells for strain $\mathrm{YN}_{101}{ }^{\mathrm{T}}(0.3-$ $1.0 \times 1.5-5.0 \mu \mathrm{m}$ ) with unambiguous flagella (Supplementary Figure S2A). Rod-shaped cells with pili are for B. sediminis FA350 ${ }^{\mathrm{T}}$ (Wang et al., 2019). Motile cells of strain $\mathrm{YN101}{ }^{\mathrm{T}}$ used flagella and gliding, which differed from cells of $B$. sediminis $\mathrm{FA} 350^{\mathrm{T}}$ that can only weakly glide (Supplementary Figure S2B). Cells of strain $\mathrm{YN}_{101}{ }^{\mathrm{T}}$ were mobile over a wider range and penetrated their prey more deeply (Pseudorhodobacter ferrugineus JCM 20687 ${ }^{\mathrm{T}}$; Uchino et al., 2002) than B. sediminis FA350 ${ }^{\mathrm{T}}$. M. xanthus $\mathrm{DK} 1622^{\mathrm{T}}$ are motile by means of pili

\footnotetext{
${ }^{7}$ ggdc.dsmz.de

${ }^{8}$ rast.nmpdr.org

${ }^{9}$ www.genome.jp/kegg/

${ }^{10}$ hemi.biocuckoo.org

${ }^{11}$ www.ncbi.nlm.nih.gov
} 


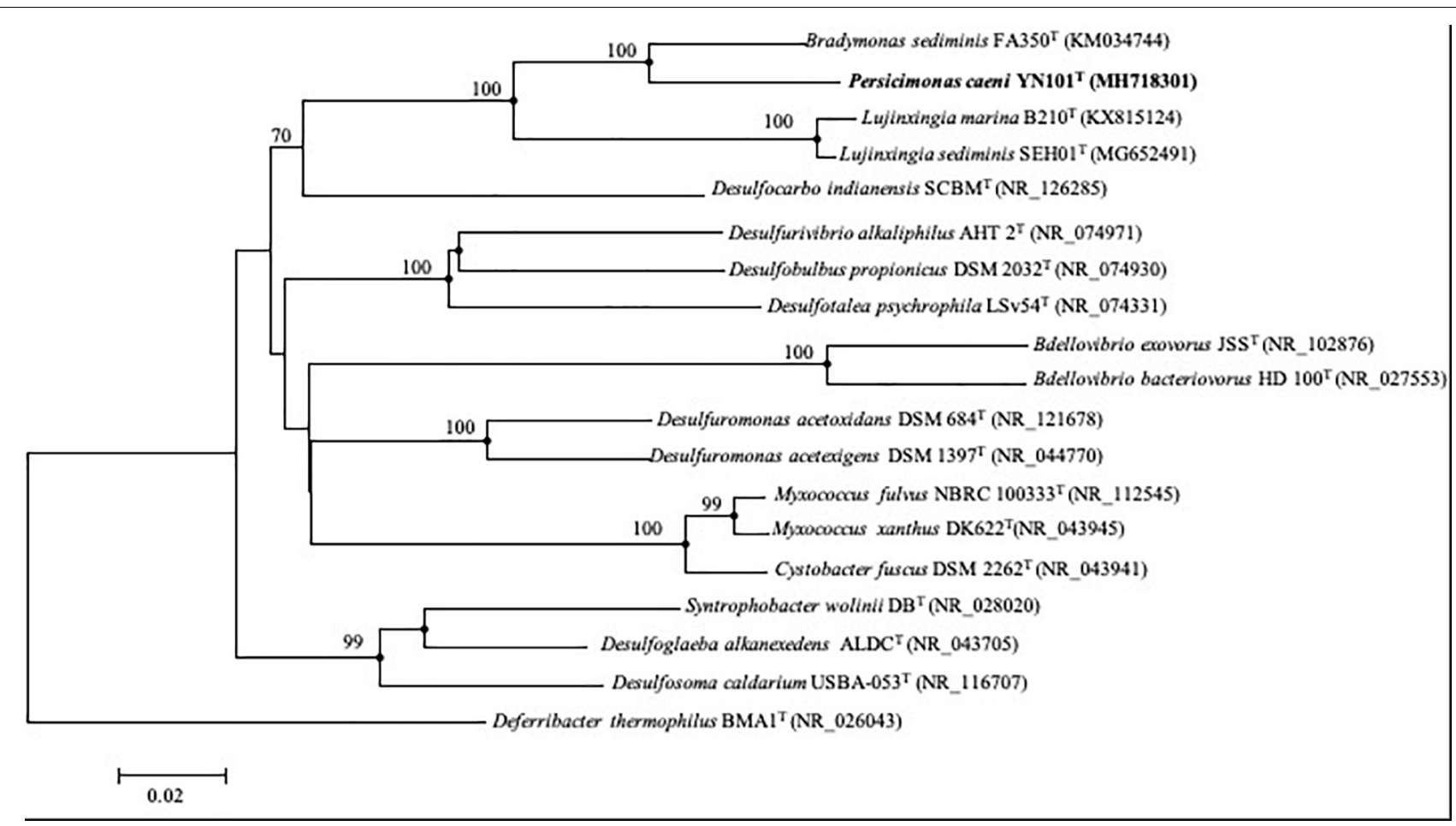

FIGURE 1 | Phylogenetic tree constructed from 16S rRNA gene sequences, showing the position of strain YN101 $^{\top}$ and type strains of related taxa within the phylum Proteobacteria. The tree was constructed using the neighbor-joining algorithm. The filled circles indicate that the corresponding nodes were also found in the trees generated with the maximum-likelihood and maximum-parsimony algorithms. Bootstrap values (expressed as percentages of 1000 replications) > $70 \%$ are shown at branch points. GenBank accession numbers of 16S rRNA gene sequences are given in parentheses. Deferribacter thermophilus BMA1' (NR_026043) was used as an outgroup. Bar, 0.02 substitutions per nucleotide position.

(Sun et al., 2000), whereas members of Bdellovibrio move using flagella (Lambert et al., 2006).

Inoculated plates were incubated at $37^{\circ} \mathrm{C}$ for up to 6 days. Cells of strain $\mathrm{YN} 101^{\mathrm{T}}$ were shown to be resistant to vancomycin (30 $\mu \mathrm{g})$, kanamycin $(30 \mu \mathrm{g})$ and tobramycin $(10 \mu \mathrm{g})$, and were susceptive to lincomycin $(2 \mu \mathrm{g})$, norfloxacin $(30 \mu \mathrm{g})$, penicillin $(10 \mu \mathrm{g})$, neomycin $(30 \mu \mathrm{g})$, clindamycin $(30 \mu \mathrm{g})$, tetracycline $(30 \mu \mathrm{g})$, ceftriaxone $(30 \mu \mathrm{g})$ and erythromycin $(15 \mu \mathrm{g})$. The related strain, B. sediminis FA350 ${ }^{\mathrm{T}}$, was shown to be extremely sensitive to penicillin $(10 \mu \mathrm{g})$, erythromycin $(15 \mu \mathrm{g})$, chloromycetin $(30 \mu \mathrm{g})$, clarithromycin $(15 \mu \mathrm{g})$, rifampicin $(5 \mu \mathrm{g})$ and cefotaxime $(30 \mu \mathrm{g})$, and were resistant to tetracycline (30 $\mu \mathrm{g})$, trimethoprim (5 $\mu \mathrm{g})$, nalidixic acid $(30 \mu \mathrm{g})$ and vancomycin $(30 \mu \mathrm{g})$.

\section{Chemotaxonomic Characteristics}

Strain $\mathrm{YN}_{101}{ }^{\mathrm{T}}$ was shown to utilize nitrate but not sulfate as an electron acceptor for anaerobic respiration, which was consistent with B. sediminis $\mathrm{FA} 350^{\mathrm{T}}$. Both strain $\mathrm{YN}_{101}{ }^{\mathrm{T}}$ and B. sediminis $\mathrm{FA} 350^{\mathrm{T}}$ tested negative for oxidase activity, but positive for catalase and nitrate reduction. Iso- $\mathrm{C}_{17: 0}(54.8 \%)$ was the only major fatty acid detected in strain $\mathrm{YN}_{101}{ }^{\mathrm{T}}$, and other component of fatty acids were lower than $10.0 \%$. However, B. sediminis $\mathrm{FA} 350^{\mathrm{T}}$ contained three major fatty acids, including iso- $\mathrm{C}_{15: 0}(40.9 \%), \mathrm{C}_{17: 0}(30.7 \%)$ and iso- $\mathrm{C}_{17: 1} \omega 10 c(13.7 \%)$.
Further details differentiating strain $\mathrm{YN}_{101}{ }^{\mathrm{T}}$ from B. sediminis FA350 ${ }^{\mathrm{T}}$ are shown in Table 1 and Supplementary Table S1. The sole respiratory quinone of strain $\mathrm{YN} 01^{\mathrm{T}}$ was $\mathrm{MK}-7$, which concurred with the related strain.

The major polar lipids detected in strain $\mathrm{YN}_{101}{ }^{\mathrm{T}}$ were phosphatidylglycerol (PG), phosphatidylethanolamine (PE), diphosphatidylglycerol (DPG), and an unidentified aminophospholipid (APL). Additionally, an unidentified phosphatidylcholine (PC) was detected in moderate or minor amounts (Supplementary Figure S3). PG, PE, and DPG were detected as the major polar lipids in B. sediminis $\mathrm{FA} 350^{\mathrm{T}}$, and unidentified APL as well as PC was detected in moderate and or minor amounts. Therefore, the polar lipid profiles differed between strain $\mathrm{YN}_{101}{ }^{\mathrm{T}}$ and the genus Bradymonas. Further details of the polar lipid contents of strain $\mathrm{YN}_{101}{ }^{\mathrm{T}}$ and the related strain B. sediminis $\mathrm{FA} 350^{\mathrm{T}}$ are shown in Supplementary Figure S3. Other details differentiating strain $\mathrm{YN}_{101}{ }^{\mathrm{T}}$ and the related genera are listed in Table 2 .

\section{Phenotypic Characteristics of Predation}

The predatory range of strain $\mathrm{YN}_{101}{ }^{\mathrm{T}}$ was investigated for activity against 27 different species of bacteria isolated from marine and saltern environments, which included Gram-stain negative bacteria and Gram-stain positive bacteria (data not shown). Four representative species were selected for further 
TABLE 1 | Phenotypic characteristics that distinguish Persicimonas from the neighbor genera.

\begin{tabular}{|c|c|c|c|}
\hline Characteristics & 1 & 2 & $3^{\S}$ \\
\hline Habitat & Saltern sludge & Marine sediment & Marine sediment \\
\hline Colony color & Pink & Orange-red & Orange \\
\hline Cell size $(\mu \mathrm{m})$ & $0.5 \times 1.0-2.5$ & $0.3-1.0 \times 1.5-5.0$ & $0.3-0.5 \times 1.8-5.1$ \\
\hline Means of motility & Flagella and gliding & Weakly gliding & Gliding \\
\hline Temperature Range $\left({ }^{\circ} \mathrm{C}\right)$ & $15-50$ & $20-37$ & $20-42$ \\
\hline $\mathrm{NaCl}$ tolerance $(\%, \mathrm{w} / \mathrm{v})$ & $1-10$ & $1-9$ & $0-8$ \\
\hline Catalase reaction & - & + & + \\
\hline Nitrate reduction & - & + & - \\
\hline Arginine hydrolase & + & - & - \\
\hline D-glucose oxidation & + & - & + \\
\hline Tryptophan deaminase & - & + & + \\
\hline Major fatty acids & Iso- $\mathrm{C}_{17: 0}$ & Iso- $\mathrm{C}_{17: 1} \omega 10 c, \mathrm{C}_{15: 0}$, iso- $\mathrm{C}_{17: 0}$ & Iso- $\mathrm{C}_{15: 0}$ and iso- $\mathrm{C}_{14: 0} 3-\mathrm{OH}$ \\
\hline Major polar lipids & DPG, PG, PE, APL & DPG, PG, PE & DPG, PG, PE, L \\
\hline Genome size (Mbp) & 8.0 & 5.0 & $5.0-5.3$ \\
\hline $\mathrm{G}+\mathrm{C}$ content (mol\%) & 63.8 & 61.1 & $63.6-64.7$ \\
\hline
\end{tabular}

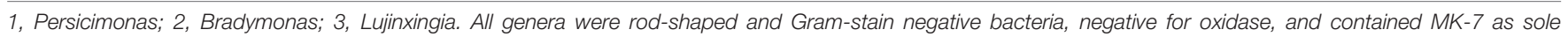
respiratory quinone. ${ }^{\S}$ Data from Guo et al. (2019).

analyzed, including three Gram-stain negative and one Gramstain positive species. Especially, Woeseiaceae and Nocardioides were the representatives of sulfur-metabolism and antibioticproduction groups (Mußmann et al., 2017; Ortiz-López et al., 2018). These functional bacteria groups were the focus on studies about global material circulation and new sources exploration of antibiotics, recently. Especially, bacterial predations can influence

TABLE 2 | Phenotypic characteristics that distinguish Persicimonas caeni $\mathrm{YN}_{101}{ }^{\top}$ from Bradymonas sediminis $\mathrm{FA}_{35}{ }^{\top}$.

\begin{tabular}{|c|c|c|}
\hline Characteristics & 1 & 2 \\
\hline \multicolumn{3}{|l|}{ Enzyme activities } \\
\hline Esterase (C4) & - & + \\
\hline Lipase (C14) & - & + \\
\hline Valine arylamidase & - & + \\
\hline Cystine arylamidase & - & + \\
\hline Trypsin & - & + \\
\hline Acid phosphatase & + & - \\
\hline Arginine hydrolase & + & - \\
\hline Tryptophan deaminase & - & + \\
\hline \multicolumn{3}{|l|}{ Carbon oxidation } \\
\hline D-Raffinose & - & + \\
\hline$\alpha$-D-Glucose & - & + \\
\hline$\alpha-K e t o-G l u t a r i c ~ a c i d$ & + & - \\
\hline Acetic Acid & - & + \\
\hline \multicolumn{3}{|l|}{ Acids production } \\
\hline D-Fructose & + & - \\
\hline L-Sorbose & + & - \\
\hline D-Lyxose & + & - \\
\hline
\end{tabular}

1, Persicimonas caeni $\mathrm{YN} 101^{\top}$; 2, Bradymonas sediminis $\mathrm{FA} 350^{\top}$. The type strains of both genera were positive for alkaline phosphatase, esterase lipase (C8), leucine arylamidase, naphthol-AS-BI-phosphohydrolase and gelatinase; produced acids from D-ribose, esculin, D-tagatose and potassium 5-ketogluconate; oxidized D-glucuronic acid, glucuronamide and acetoacetic acid. +, Positive; -, negative. the variations and abundances of microorganism (Pérez et al., 2016). Studies on these preys could help discuss about effects of predation on natural material circulations.

After cross-streaking incubation of strain $\mathrm{YN} 101^{\mathrm{T}}$ and the test bacteria, plates were incubated until the growth of both bacteria was indicated by visible lawn (Supplementary Figure S1A). When strain $\mathrm{YN} 101^{\mathrm{T}}$ preyed on test bacteria like Nocardioides gilvus XZ17 ${ }^{\mathrm{T}}$ (Zhang et al., 2016), Woeseia oceani XK5 ${ }^{\mathrm{T}}$ (Du et al., 2016) and A. marinus am $2^{\mathrm{T}}$, the predator could be detected by $16 \mathrm{~S}$ rRNA gene sequencing in the second line (Supplementary Figure S1B), but the test bacteria not. However, when the predator did not feed on the test bacteria, such as Algoriphagus resistens $\mathrm{NH}^{\mathrm{T}}$ (Han et al., 2017c), strain $\mathrm{YN} 101^{\mathrm{T}}$ could only be detected in the first line. Results of cross-streaking tests incubating B. sediminis $\mathrm{FA} 350^{\mathrm{T}}$ and the same test bacteria are also shown in Supplementary Figure S1A. Predation occurred with cell-to-cell attachment, and biofilm formation could be observed during the whole process.

Biomass fluctuations of predators, strain $\mathrm{YN} 101^{\mathrm{T}}$ and B. sediminis $\mathrm{FA} 350^{\mathrm{T}}$, and prey, A. marinus am $2^{\mathrm{T}}$, after monoand co-culture for 0, 68, and $120 \mathrm{~h}$ are demonstrated in Figure 2. The gene copy number of prey co-cultured with strain $\mathrm{YN}_{101}{ }^{\mathrm{T}}$ decreased from $1.9 \times 10^{9}$ to $7.9 \times 10^{6}$ copies $/ \mu \mathrm{L}$ at $120 \mathrm{~h}$. However, cell numbers of the mono-cultured prey showed no significant change. Order of magnitudes of both mono- and co-cultured strain $\mathrm{YN}_{101}{ }^{\mathrm{T}}$ increased by approximately 1.5 , but growth of the co-cultured cells was slightly larger, indicating that the predator strain $\mathrm{YN}_{10} 1^{\mathrm{T}}$ grew by killing prey $A$. marinus $\mathrm{am} 2^{\mathrm{T}}$. The gene copy number of $A$. marinus am $2^{\mathrm{T}}$ decreased from $5.0 \times 10^{9}$ to $3.9 \times 10^{8}$ copies/ $\mu \mathrm{L}$ at $120 \mathrm{~h}$ when co-cultured with $B$. sediminis $\mathrm{FA} 350^{\mathrm{T}}$. Co-cultured $B$. sediminis $\mathrm{FA} 350^{\mathrm{T}}$ had a consistent increase in logarithmic gene copy number values, with greater amplification than for mono-cultured cells. The above results implied that strain $\mathrm{YN}_{101}{ }^{\mathrm{T}}$ and $B$. sediminis FA $350^{\mathrm{T}}$ are bacterial predators. Quantitative standard curves of specific genes are shown in Supplementary Figure S7, 


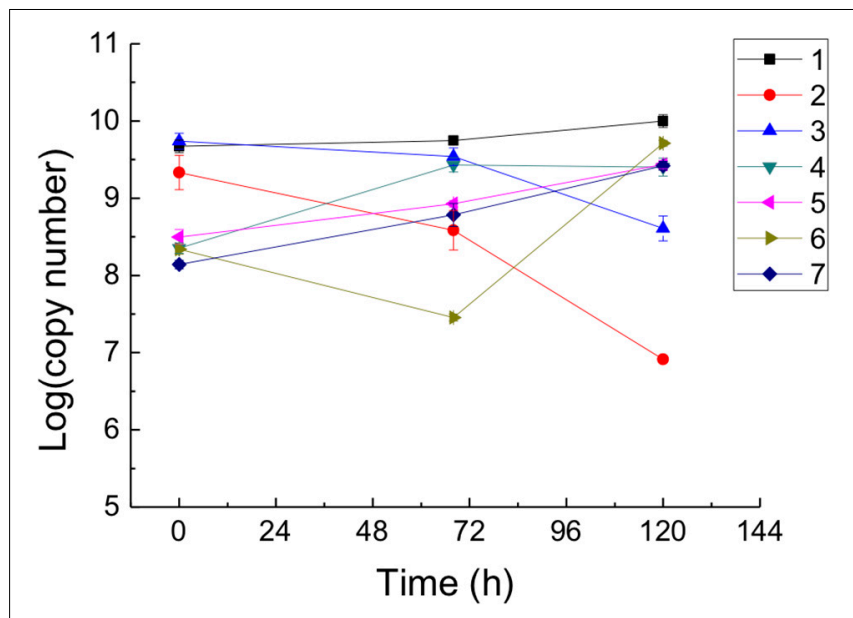

FIGURE 2 | Biomass quantifying of strain $\mathrm{YN} 101^{\top}$, B. sediminis $\mathrm{FA} 350^{\top}$ and prey Algoriphagus marinus am $2^{\top}$ mono-cultured and co-cultured for different time $(0,68$, and $120 \mathrm{~h})$ using fluorogenic quantitative PCR. Horizontal axis represented incubation time, and vertical axis represented the logarithm of gene copy number. 1, A. marinus am2 ${ }^{\top}$ (RuBisCO); 2, P. caeni ${\mathrm{YN} 101^{\top} \text { and }}^{\top}$ A. marinus am2 ${ }^{\top}$ (RuBisCO); 3, B. sediminis $F A 350^{\top}$ and $A$. marinus am2 ${ }^{\top}$

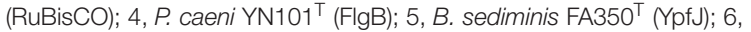
P. caeni $\mathrm{YN}^{\mathrm{N} 101^{\top}}$ and $A$. marinus am2 ${ }^{\top}$ (FlgB); 7, B. sediminis $\mathrm{FA} 350^{\top}$ and A. marinus am $2^{\top}$ (YpfJ). Each design was repeated three times, and the result was the average of the three replicates.

and data from fluorescent quantitative PCR are shown in Supplementary File S2.

The predatory features were summarized as below. Strain $\mathrm{YN} 101^{\mathrm{T}}$ predated a wide range of bacterial species, no matter Gram-stain negative or Gram-stain positive bacteria, which was similar with myxobacteria. Chemotactic predation by gliding occurred in strain $\mathrm{YN}_{101}{ }^{\mathrm{T}}$ when living on surface, but not very extremely as myxobacteria. Predation depended on cell-to-cell contact, and predation in liquid was not observed. Details of predatory features were list in Table 3.

\section{Genome Data and Comparative Genomic Analysis}

The completed genome of strain $\mathrm{YN}_{101}{ }^{\mathrm{T}}$ was assembled into a single circular chromosome of 8,047,306 bp (144.4fold coverage) and coded 6009 proteins, similar to the genome size $(9,139,763 \mathrm{bp})$ and gene number (7,181 CDS) of $M$. xanthus DK1622 $2^{\mathrm{T}}$. B. sediminis $\mathrm{FA} 350^{\mathrm{T}}$ contained a genome of 5,045,683 bp (Wang et al., 2019), similar in size to the genome of Bdellovibrio. Genomes of strain $\mathrm{YN} 101^{\mathrm{T}}, B$. sediminis $\mathrm{FA} 350^{\mathrm{T}}$ and $M$. xanthus $\mathrm{DK} 1622^{\mathrm{T}}$ had similar $\mathrm{G}+\mathrm{C}$ content (mol\%) of $60-70 \%$. The $\mathrm{dDDH}$ value between strain $\mathrm{YN}_{101}{ }^{\mathrm{T}}$ and $B$. sediminis $\mathrm{FA} 350^{\mathrm{T}}$ was $13.9 \%$, and the ANI value between the two strains was $74.0 \%$. More details about the genomes of five predators are shown in Table 4. A phylogenomic tree built upon the sequences of 92 core genes ( $\mathrm{Na}$ et al., 2018) using the maximum likelihood algorithm showed the same taxonomic status of strain $\mathrm{YN}_{101}{ }^{\mathrm{T}}$ (Figure 3). The taxonomic status of strain $\mathrm{YN} 01^{\mathrm{T}}$ in the phylogenomic tree was consistent with the phylogenetic tree built according to $16 \mathrm{~S}$ rDNA gene sequence analyses.

In addition, comparative genomic analyses between strain $\mathrm{YN}_{101^{\mathrm{T}}}$ and $B$. sediminis $\mathrm{FA} 350^{\mathrm{T}}$ showed that strain $\mathrm{YN}_{101}{ }^{\mathrm{T}}$ encoded 189 functional genes more than its neighbor. These genes included hydrogenase metallocentre assembly proteins, ammonium transporter, $\beta$-ketoadipate enol-lactone hydrolase, dethiobiotin synthetase, chemotaxis regulator (CheY), ATP synthase $\mathrm{F}_{0}$ sector subunits, etc., as well as many other proteins. Most of these proteins were mainly affiliated with metabolism of many important amino acids, hydrogenase expression/formation, $\mathrm{ABC}$ transporters synthesis, benzoate degradation, biotin metabolism, purine metabolism, two-component systems, chemotaxis family and flagellar assembly. Especially these genes encoding synthesis and assembly of flagellum, made strain $\mathrm{YN} 101^{\mathrm{T}}$ behaved more athletic than $B$. sediminis $\mathrm{FA} 350^{\mathrm{T}}$ (Supplementary Figure S2B).

A total of 1,335 common genes in the genomes of five predators could be annotated according to RAST. Strain $\mathrm{YN}_{101}{ }^{\mathrm{T}}$ and $B$. sediminis $\mathrm{FA} 350^{\mathrm{T}}$ possessed 508 common genes (Supplementary Figure S4), which were affiliated with transportation of oligopeptides, biosynthesis and degradation of several amino acids, and assembly of type IV pili. M. xanthus DK1622 $2^{\mathrm{T}}$ and strain $\mathrm{YN} 101^{\mathrm{T}}$ encoded 369 common genes related to transportation of branched-chain amino acids, and adaptation and accommodation to extreme living environments. In addition, 116 common genes contained by all five predators were affiliated with bacterial growth, metabolism and reproduction (Supplementary Figure S4). These genes participated in catabolic pathways of various nutrients, DNA replication, transcription, translation and repair, carbon cycle pathways, nitrogen cycle pathways, and

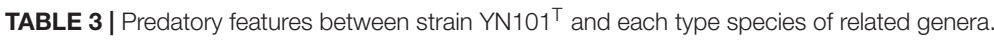

\begin{tabular}{|c|c|c|c|c|c|}
\hline Predatory features & 1 & 2 & 3 & $4^{\S}$ & $5^{\S}$ \\
\hline Range of prey & $\mathrm{G}^{+}$and $\mathrm{G}^{-}$ & $\mathrm{G}^{+}$and $\mathrm{G}^{-}$ & $\mathrm{G}^{+}$and $\mathrm{G}^{-}$ & $\mathrm{G}^{-}$ & $\mathrm{G}^{-}$ \\
\hline Predating strategy & Epibiotic & Epibiotic & Group attack & Periplasmic & Epibiotic \\
\hline Predation in liquid & - & - & + & + & + \\
\hline
\end{tabular}

1, Strain YN101'; 2, Bradymonas sediminis FA350' ; 3, Myxococcus xanthus DK1622' ; 4, Bdellovibrio bacteriovorus HD100'; 5, Bdellovibrio exovorus JSS ${ }^{\top}$. +, Positive; -, negative; $G^{+}$, Gram-positive; $G^{-}$, Gram-negative; W, weakly. ${ }^{\S}$ Data from Pérez et al. (2016). 
TABLE 4 | Genetic distinction between strain $\mathrm{YN} 101^{\top}$ and each type species of related genera.

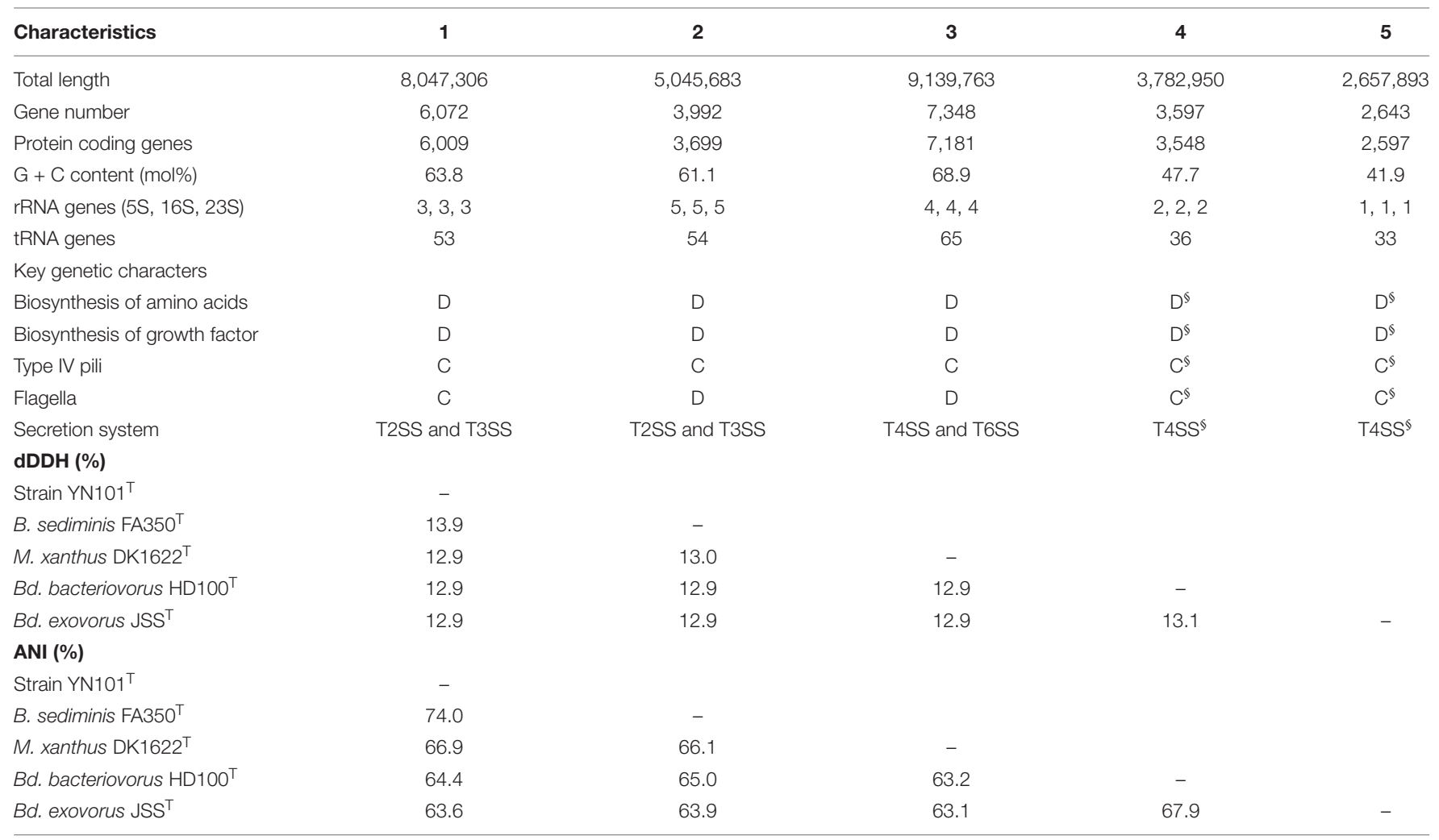

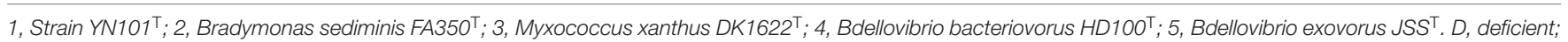
C, complete. ${ }^{\S}$ Data from Pérez et al. (2016).

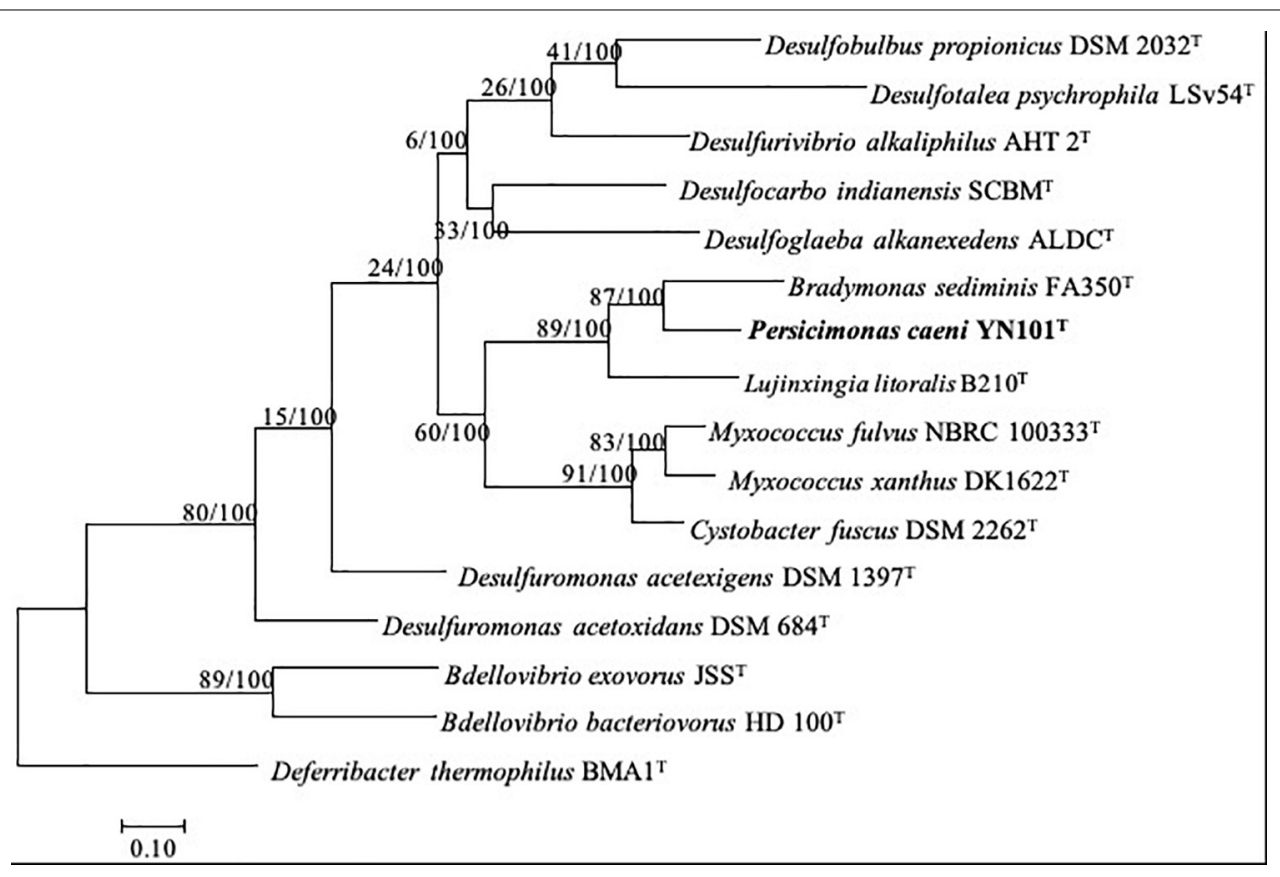

FIGURE 3 | Phylogenomic tree based on up-to-date bacterial core gene sequences of strain $\mathrm{YN} 101^{\top}$ and type strains of related genera within the phylum Proteobacteria. The tree was constructed using maximum-likelihood algorithm. Gene support indices (GSIs) and percentage bootstrap values are given at branching points. Bar, 0.10 substitutions per nucleotide position. 


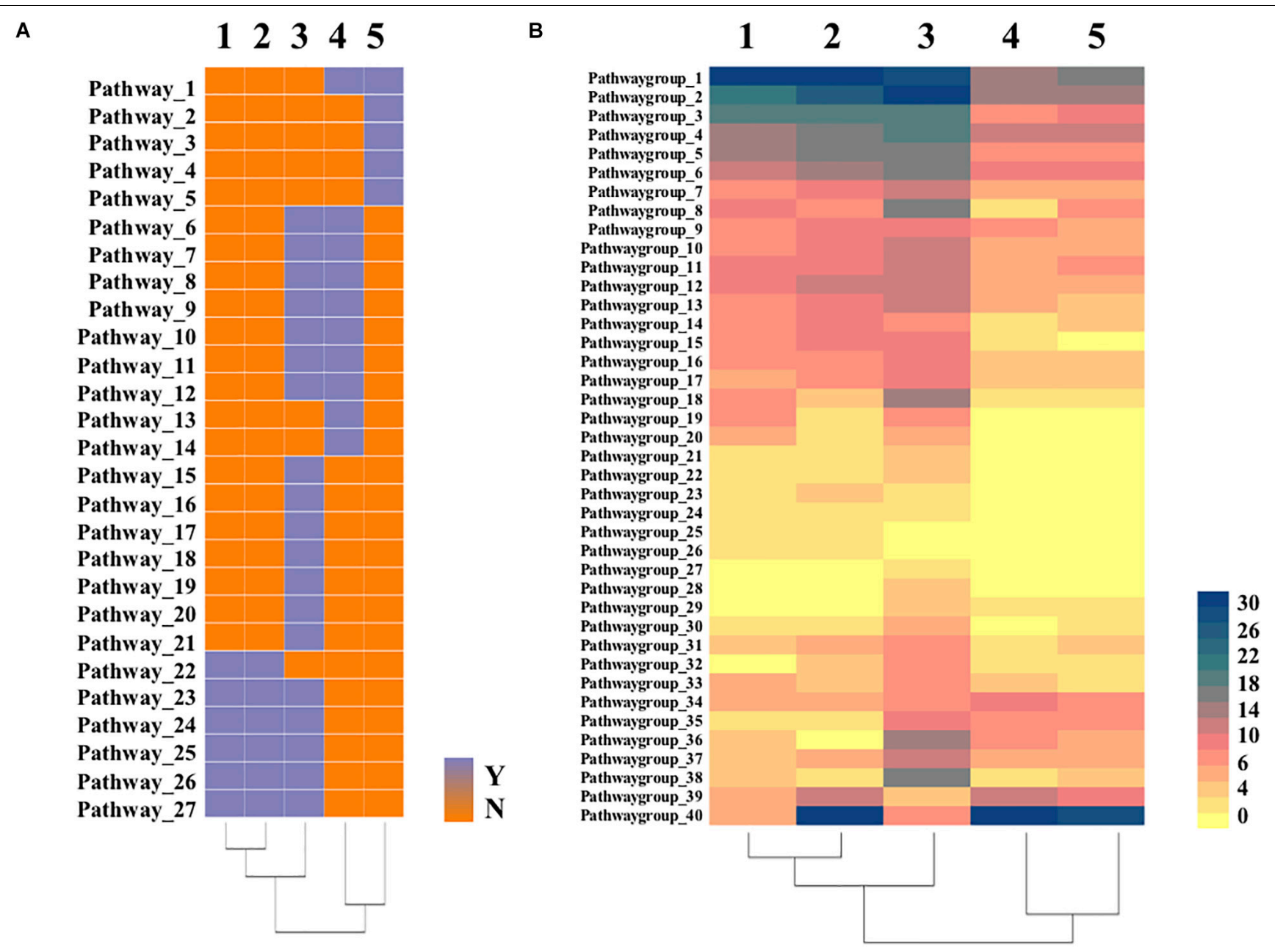

FIGURE 4 | Heatmaps of comparative genomic analysis between strain YN101 ${ }^{\top}$ and related strains. (A) heatmap clustered with 27 pathways according to annotation of the RAST and KEGG; (B) heatmap clustered with gene numbers of 40 metabolism groups according to annotation of the RAST and KEGG. 1, Strain YN101 ${ }^{\top}$; 2, Bradymonas sediminis FA350 ${ }^{\top}$; 3, Myxococcus xanthus DK1622 ${ }^{\top}$; 4, Bdellovibrio bacteriovorus HD100 $^{\top}$; 5, Bdellovibrio exovorus JSS ${ }^{\top}$.

oxidation respiratory chain (Supplementary Figure S5 and Supplementary File S3).

To further detect differences between Bradymonadales and other predators, heatmaps (Figure 4 and Supplementary Files S4, S5) were constructed according to RAST and KEGG annotations. Strain $\mathrm{YN}_{101}{ }^{\mathrm{T}}$ and $B$. sediminis $\mathrm{FA} 350^{\mathrm{T}}$ lost the complete biosynthesis pathways of threonine, histidine, phenylalanine, valine, leucine, and isoleucine. Biosynthesis metabolism of glycine, serine, methionine and arginine existed in the cells of strain $\mathrm{YN}_{101}{ }^{\mathrm{T}}$ and $B$. sediminis FA350 ${ }^{\mathrm{T}}$, however, these amino acids were not de novo synthesized by Bdellovibrio. M. xanthus $\mathrm{DK} 1622^{\mathrm{T}}$ did not synthesize histidine, some aromatic amino acids (tyrosine and phenylalanine), and branched amino acids (valine, leucine and isoleucine). Moreover, the type II and type III secretory system (T2SS and T3SS) of strain $\mathrm{YN}_{101}{ }^{\mathrm{T}}$ and B. sediminis $\mathrm{FA} 350^{\mathrm{T}}$ was more complete than other types of secretory systems, in spite of lacking two transporters named GspS and GspO.
The genetic feature of strain $\mathrm{YN} 101^{\mathrm{T}}$ were summarized as below. Strain ${\mathrm{YN} 101^{\mathrm{T}}}$ yielded a large genome of 8,047,306 bp, which encoded 189 functional genes more than $B$. sediminis FA350 ${ }^{\mathrm{T}}$ (according to the analyses of RAST). Its genome encoded many genes affiliated with Type IV pili, Type II secretion system, membrane proteins and transduction proteins, which assisted itself to locate and lyse prey bacteria, and uptake the nutrient from the prey bacteria. The biosynthesis of many important compounds was deficient, which may result in the predation of other bacteria. Genes about flagellum assembly were encoded, thus the strain possessed good athletic ability. Details about genetic features were list in Table 4.

\section{DISCUSSION}

Bradymonadales are abundant not only in marine environments, but also in high-salinity inland water 
environments including saline soil environments (Wang et al., 2015; Bachran et al., 2019; Guo et al., 2019). As a novel member of Bradymonadales, strain $\mathrm{YN}_{101}{ }^{\mathrm{T}}$ has numerous features in common with $B$. sediminis $\mathrm{FA} 350^{\mathrm{T}}$ that differentiate it from other predatory bacterial groups. Cells of strain $\mathrm{YN} 01^{\mathrm{T}}$ are facultatively anaerobic, motile, and prey on a broad spectrum of bacteria. Members of Bradymonadales are different facultative predators from Bdellovibrio and like organisms (BALOs), and their prey and predatory strategies are distinct from those of myxobacteria. Therefore, comparative analyses about its respiratory pattern, motility and predatory characters with Myxobacteria in Deltaproteobacteria and BALOs in Oligoflexia were discussed as below.

Many members in the class Deltaproteobacteria can utilize sulfate, sulfite, thiosulfate, sulfur or some other inorganic compounds as their terminal electron acceptors (Wang et al., 2015). However, strain $\mathrm{YN}_{101}{ }^{\mathrm{T}}$ and $B$. sediminis $\mathrm{FA} 350^{\mathrm{T}}$ could utilize nitrate as electron acceptors for anaerobic respiration. Genomic analyses performed via RAST indicated that two enzymes, EC 1.7.1.4 and EC 1.7.2.1, were encoded by the genome of strain $\mathrm{YN}_{101}{ }^{\mathrm{T}}$, which were key to the process of passing electrons from $\mathrm{NAD}(\mathrm{P}) \mathrm{H}$ to nitrate. One flavodoxin reductase (ferredoxin-NADPH reductases) gene, one ferredoxin reductase gene and one arsenate reductase (EC 1.20.4.1) gene were affiliated with anaerobic respiration. Four genes were affiliated with oxidative stress in strain $\mathrm{YN} 101^{\mathrm{T}}$ while two genes were affiliated in the related strain, B. sediminis $\mathrm{FA} 350^{\mathrm{T}}$. Strain $\mathrm{YN} 101^{\mathrm{T}}$, rather than $B$. sediminis FA350 $0^{\mathrm{T}}$, possessed the peroxide stress regulator and hydrogen peroxide-inducible gene activator. Therefore, we predict that Bradymonadales may possess the evolutionary status of connecting anaerobic and aerobic groups in the class Deltaproteobacteria.

Motility is a general property of both obligate and facultative bacterial predators (Lambert et al., 2006; Mendes-Soares and Velicer, 2013). Bdellovibrio bacteriovorus runs into the prey during the attack phase propelled by flagellum motility in liquid media, or by slow gliding motility on solid media, and $M$. xanthus groups actively swarm toward the prey using gliding motility (Pérez et al., 2016). As a novel bacterial predator, cells of strain $\mathrm{YN} 101^{\mathrm{T}}$ move by means of flagella and $B$. sediminis $\mathrm{FA} 350^{\mathrm{T}}$ with pili (Supplementary Figure S2A and Table 1), and motility by flagella being more tempestuous than that by pili (Supplementary Figure S2B). Cross-streaking experiments also demonstrated this mode of motility during predation (Supplementary Figure S1A). Cells of strain $\mathrm{YN}_{101}{ }^{\mathrm{T}}$ and B. sediminis $\mathrm{FA} 350^{\mathrm{T}}$ attack prey from the front direction rather than from both sides (Supplementary Figure S2B). Furthermore, based on genetic analyses, the genome of strain $\mathrm{YN}_{101}{ }^{\mathrm{T}}$ encoded genes affiliated with flagellar motility, which were not encoded by the genome of $B$. sediminis FA350 ${ }^{\mathrm{T}}$. Among these genes, $f l h B, f l i R, f l h F$, and $f h A$ participated in the biosynthesis of flagella; and fliN, $\operatorname{mot} A$, and $\operatorname{mot} B$ were responsible for motor switch and rotation of flagella. In addition, gene $f l g H$ was also found, which could help export the flagellar L-ring proteins across the cell membrane to their destinations in the outer membrane. Apart from the genes described above, genes fliI, flgD, and cheY were also encoded by the genome of strain $\mathrm{YN}_{101}{ }^{\mathrm{T}}$. Distinctions among the motility of members of Bradymonadales give rise to different extents of predation (Supplementary Figure S2B), which may be induced by their genomic differences.

Members of Bradymonadales prey on a relatively broad range of bacterial types. Thus, we selected 4 representative species (Supplementary Figure S1) for further analyses. Woeseiaceae, abundant in both coastal and deep-sea sediments (Bacosa et al., 2018), oxidize sulfite and degrade hydrocarbons, suggesting that members of Woeseiaceae are functional in carbon, sulfur and nitrogen cycling in diverse marine sediment types (Mußmann et al., 2017; Bacosa et al., 2018). Especially, some members of the Woeseiaceae also have the genetic potential for chemolithoautotrophy powered by sulfur or hydrogen oxidation (Mußmann et al., 2017). Meanwhile, Algoriphagus is widely distributed in the marine environment. Studies report certain members of Algoriphagus can encode a carotenoid synthesis gene cluster (Tao et al., 2006), indicating Algoriphagus bacteria may have influences on marine animal cell biology (Alegado et al., 2012). Nocardioides is one important representative taxon of actinomycetes, which can produce antibiotics (Matson and Bush, 1989; Ortiz-López et al., 2018), and its members inhabit different natural surroundings, including soil, cave, seawater and desert (Zhang et al., 2016; Khan et al., 2017; Lu et al., 2017; Wang et al., 2017). These three species represented bacterial groups associated with sulfur metabolism, pigments and antibiotic production. Moreover, predator-prey interactions play important roles in the cycling of marine organic matter. For instance, some bacterial predators bind to the glycan strands of Gram-stain positive bacterial peptidoglycan (PG) and degrades the PG peptide chains, leading to cell death (Tang et al., 2020). The released nutrients, including PG-derived D-amino acids, can then be utilized by these predators for growth. Additionally, for the formation of biofilm during predation, the order Bradymonadales may play important roles in structuring the marine particle- and surface-associated microbial community composition (Dang and Lovell, 2016). On surfaces and particles, higher encounter rate may accelerate predation rate other than these individual microbes free-living in seawater. Therefore, predation on these three diverse groups of bacteria indicated that the order Bradymonadales may play a significant role in regulating marine microbial communities and the global biochemical cycle.

Furthermore, we found that both strain $\mathrm{YN}_{101}{ }^{\mathrm{T}}$ and B. sediminis $\mathrm{FA} 350^{\mathrm{T}}$ showed different predatory behaviors to different species of the same genus. For instance, two predators could prey on A. marinus am $2^{\mathrm{T}}$ and $N$. gilvus $\mathrm{XZ1}^{\mathrm{T}}$ but not on $A$. resistens $\mathrm{NH}^{\mathrm{T}}$ and $N$. albus JCM $3185^{\mathrm{T}}$. Cross-streaking experiments qualitatively demonstrated the predation behavior of two predators but could not quantitatively measure how the biomasses of predators and prey change during this process. Therefore, A. marinus am $2^{\mathrm{T}}$ was chosen as prey for strain $\mathrm{YN} 101^{\mathrm{T}}$ 
and $B$. sediminis $\mathrm{FA} 350^{\mathrm{T}}$ for absolute quantification by fluorescent quantitative PCR. Three time periods were representative of prophase, metaphase and anaphase of the predation process, which were demonstrated by colony-counting results using the plate culture technique (Supplementary Figure S6). As shown in Figure 2, two co-cultured predators killed A. marinus am $2^{\mathrm{T}}$ and their biomasses increased. Furthermore, their biomass increases were greater than those observed in the mono-cultured control groups. Cell numbers of mono-cultured prey indicated A. marinus am $2^{\mathrm{T}}$ grew normally without predatory stress. Therefore, we considered that the decrease of $A$. marinus am $2^{\mathrm{T}}$ and increases of strain $\mathrm{YN} 101^{\mathrm{T}}$ and $B$. sediminis FA $350^{\mathrm{T}}$ in the co-cultured system were caused by the latter two microorganisms preying on A. marinus $\mathrm{am}^{\mathrm{T}}$. Deviations in the extraction of the sample genome might have given rise to a small reduction of co-cultured strain YN101 $1^{\mathrm{T}}$ at $68 \mathrm{~h}$.

As shown in Figure 4A, all five predators lost their ability to de novo synthesize several amino acids. Some obligate epibiotic predators depend on prey strictly because their genomes do not encode genes to synthesize certain amino acids or to import them directly from the environment (Wang et al., 2011; Soo et al., 2015). Predatome results exhibited deficiencies in riboflavin and amino acids biosynthesis, suggesting that predators obtain these molecules from their prey (Pasternak et al., 2013). In other words, predation is one important approach by these organisms to uptake certain kinds of amino acids. Figure 4B demonstrated the differences in gene numbers of 40 metabolism groups from the five predators. Strain $\mathrm{YN}_{101}{ }^{\mathrm{T}}$ and $B$. sediminis FA $350^{\mathrm{T}}$ had more complete pathways than Bdellovibrio for the biosynthesis of some amino acids, fatty acids and carbohydrates. However, biosynthesis of threonine, valine, leucine, isoleucine, lysine, histidine, phenylalanine, and tyrosine were still incomplete, which may induce to the predation of Bradymonadales.

Strain $\mathrm{YN}_{101}{ }^{\mathrm{T}}$ and B. sediminis $\mathrm{FA} 350^{\mathrm{T}}$ encoded many genes affiliated with secretion system (including T2SS and T3SS) and signal transduction system. Moreover, type IV pilus (T4P) were also found in the genomes of Bradymonadales. Bradymonadales might invade Gram-negative bacteria during the predation process, and it was necessary to locate the prey by sliding T4P on the surface of the substrate. T4P also consisted the attachment structure to prey cells. Secretion system might participate in the process of predation by secreting antibiotics and hydrolases to kill or lyse the prey cells (Pérez et al., 2016). T3SSs might form channels that cross the bacterial envelope and the prey cell membrane, which enable bacteria to inject numerous effector proteins into the prey cell cytoplasm and establish trans-kingdom interactions with diverse prey (Deng et al., 2017). T2SS could hypothetically be recombined with proteins replacing GspS and GspO, assisting pathogens to infect hosts. GspS is one compound of the EnvZ/OmpR two-component system that mediates the osmotic stress response in a number of Gram-stain negative bacteria, while GspO is a leader peptidase (Gueguen et al., 2013; Zhang et al., 2013). Therefore, we predicted strain $\mathrm{YN}_{101}{ }^{\mathrm{T}}$ and
B. sediminis $\mathrm{FA} 350^{\mathrm{T}}$ were probably able to prey on bacteria with participation from secretion system.

In conclusion, chemotaxonomic, physiological, and biochemical analyses distinguished strain $\mathrm{YN} 101^{\mathrm{T}}$ from its related strain, B. sediminis $\mathrm{FA} 350^{\mathrm{T}}$, and strain $\mathrm{YN} 101^{\mathrm{T}}$ is a novel predator in Deltaproteobacteria. Studies on this novel predatory group have great potential value for exploring microbial behavior and ecology. Our work lays the foundation for further study of Bradymonadales in the future.

\section{Description of Persicimonas gen. nov.}

Persicimonas (Per'si.ci.mo'nas. Gr. adj. persicus of peach; Gr. n. monas a unit, monad; N.L. fem. n. Persimonas, a peachcolored monad).

Cells are Gram-stain negative, rod-shape, facultatively anaerobic and motile. Oxidase negative and catalase positive. The major polar lipid profile consists of diphosphatidylglycerol (DPG), phosphatidylglycerol (PG), phosphatidylethanolamine (PE) and unidentified aminophospholipid (APL). The predominant cellular fatty acid is iso- $\mathrm{C}_{17: 0}$. The sole ubiquinone is MK-7. The type species is Persicimonas caeni.

\section{Description of Persicimonas caeni sp. nov.}

Persicimonas caeni (cae'ni. L. gen. n. caeni of sludge) Cells are $0.3-1.0 \mu \mathrm{m}$ in width and $1.5-5.0 \mu \mathrm{m}$ in length. Colonies were circular or irregular, pink-colored, about $1 \mathrm{~mm}$ diameter, and with entire and transparent edges. Growth occurs at $15-50^{\circ} \mathrm{C}$ (optimum $37^{\circ} \mathrm{C}$ ) and $\mathrm{pH}$ 6.5-9.0 (optimum 8.0-8.5) with 1-10 $\%(\mathrm{w} / \mathrm{v}) \mathrm{NaCl}$ (optimum 3-4 \%). Nitrate cannot be reduced to nitrite. Positive for alkaline phosphatase, esterase lipase (C8), leucine arylamidase, acid phosphatase and naphthol-AS-BIphosphohydrolase, but negative for esterase (C4), lipase (C14), valine arylamidase, cystine arylamidase, trypsin, $\alpha$-chymotrypsin, $\alpha$ - and $\beta$-galactosidase, $\beta$-glucuronidase, $\alpha$ - and $\beta$-glucosidase, $N$-acetyl- $\beta$-glucosaminidase, $\alpha$-mannosidase and $\alpha$-fucosidase. Arginine hydrolysis, gelatinase and D-glucose oxidation were positive. Negative for $\beta$-galactosidase, lysine decarboxylase, omithine decarboxylase, citrate utilization, $\mathrm{H}_{2} \mathrm{~S}$ production, urease, tryptophan deaminase, indole production, acetoin production, D-mannitol oxidation, inositol oxidation, D-sorbitol oxidation, L-rhamnose oxidation, D-saccharose oxidation, Dmelibiose oxidation, amygdaline oxidation, and L-arabinose oxidation tests. Acids are produced with the substrates Dribose, D-fructose, L-sorbose, esculin, D-xylose, D-tagatose and potassium 5-ketogluconate. D-Glucuronic, glucuronamide, $\alpha$ keto-glutaric and acetoacetic are oxidized.

The type strain, $\mathrm{YN}_{101}{ }^{\mathrm{T}} \quad\left(=\mathrm{KCTC} 72083^{\mathrm{T}}=\mathrm{MCCC}\right.$ $\left.1 \mathrm{H} 00374^{\mathrm{T}}\right)$ was isolated from a marine solar saltern $\left(122^{\circ} 14^{\prime} \mathrm{E}\right.$, $\left.36^{\circ} 54^{\prime} \mathrm{N}\right)$ on the coast of Weihai, PR China. The DNA G + C content of the type strain is $63.8 \mathrm{~mol} \%$. The GenBank accession number for the 16S rRNA gene sequence of Persicimonas caeni $\mathrm{YN} 101^{\mathrm{T}}$ is $\mathrm{MH718301}$. The complete genome sequence of strain $\mathrm{YN} 101^{\mathrm{T}}$ has been deposited at GenBank under the accession CP041186. 


\section{DATA AVAILABILITY STATEMENT}

The GenBank accession numbers for the 16S rRNA gene sequence and the whole-genome project of strain $\mathrm{YN} 101^{\mathrm{T}}$ are MH718301 and CP041186, respectively.

\section{AUTHOR CONTRIBUTIONS}

SW, DM, and Z-JD designed the experiments. SW carried out the experiments and analyzed the experimental results. SW wrote the manuscript.

\section{REFERENCES}

Alegado, R. A., Brown, L. W., Cao, S., Dermenjian, R. K., Zuzow, R., Fairclough, S. R., et al. (2012). A bacterial sulfonolipid triggers multicellular development in the closest living relatives of animals. eLife 1:e00013. doi: 10.7554/eLife. 00013

Bachran, M., Kluge, S., Lopez-Fernandez, M., and Cherkouk, A. (2019). Microbial diversity in an arid, naturally saline environment. Microb. Ecol. 78, 494-505. doi: 10.1007/s00248-018-1301-2

Bacosa, H. P., Erdner, D. L., Rosenheim, B. E., Shetty, P., Seitz, K. W., Baker, B. J., et al. (2018). Hydrocarbon degradation and response of seafloor sediment bacterial community in the northern Gulf of Mexico to light Louisiana sweet crude oil. ISME J. 12, 2532-2543. doi: 10.1038/s41396-018-0190-1

Bernardet, J. F., Nakagawa, Y., and Holmes, B. (2002). Proposed minimal standards for describing new taxa of the family Flavobacteriaceae and emended description of the family. Int. J. Syst. Evol. Microbiol. 52, 1049-1070. doi: 10. 1099/00207713-52-3-1049

Cheng, C., Wei, H., Xu, C., Xie, X., Jiang, S., and Peng, J. (2018). Maternal soluble fiber diet during pregnancy changes the intestinal microbiota, improves growth performance, and reduces intestinal permeability in piglets. Appl. Environ. Microbiol. 84, e01047-18. doi: 10.1128/AEM.01047-18

CLSI (2019). Performance Standards for Antimicrobial Susceptibility Testing, 22nd Edn Informational Supplement M100-S22. Wayne, PA: Clinical and Laboratory Standards Institute.

Cowan, S. T., and Steel, K. J. (1965). Manual for the Identification of Medical Bacteria. London: Cambridge University Press.

Dang, H. Y., and Lovell, C. R. (2016). Microbial surface colonization and biofilm development in marine environments. Microbiol. Mol. Biol. Rev. 80, 91-138. doi: 10.1128/MMBR.00037-15

Dashiff, A., Junka, R. A., Libera, M., and Kadouri, D. E. (2011). Predation of human pathogens by the predatory bacteria Micavibrio aeruginosavorus and Bdellovibrio bacteriovorus. J. Appl. Microbiol. 110, 431-444. doi: 10.1111/j.13652672.2010.04900.x

Deng, W., Marshall, N. C., Rowland, J. L., McCoy, J. M., Worrall, L. J., Santos, A. S., et al. (2017). Assembly, structure, function and regulation of type III secretion systems. Nat. Rev. Microbiol. 15, 323-337. doi: 10.1038/nrmicro. 2017.20

Du, Z. J., Wang, Z. J., Zhao, J. X., and Chen, G. J. (2016). Woeseia oceani gen. nov., sp. nov., a chemoheterotrophic member of the order Chromatiales, and proposal of Woeseiaceae fam. nov. Int. J. Syst. Evol. Microbiol. 66, 107-112. doi: 10.1099/ijsem.0.000683

Felsenstein, J. (1981). Evolutionary trees from DNA sequences: a maximum likelihood approach. J. Mol. Evol. 17, 368-376. doi: 10.1007/bf01734359

Gueguen, E., Durand, E., Zhang, X. Y., d'Amalric, Q., Journet, L., and Cascales, E. (2013). Expression of a Yersinia pseudotuberculosis type VI secretion system is responsive to envelope stresses through the OmpR transcriptional activator. PLoS One 8:e66615. doi: 10.1371/journal.pone.0066 615

Guo, L. Y., Li, C. M., Wang, S., Mu, D. S., and Du, Z. J. (2019). Lujinxingia litoralis gen. nov., sp. nov. and Lujinxingia sediminis sp. nov., two new representatives

\section{FUNDING}

This work was supported by the National Natural Science Foundation of China (31770002) and Science and Technology Basic Resources Investigation Program of China (2017FY100300).

\section{SUPPLEMENTARY MATERIAL}

The Supplementary Material for this article can be found online at: https://www.frontiersin.org/articles/10.3389/fmicb. 2020.00698/full\#supplementary-material

in the order Bradymonadales. Int. J. Syst. Evol. Microbiol. 69, 2767-2774. doi: 10.1099/ijsem.0.003556

Han, J. R., Fang, D. B., Xia, H. F., Chen, G. J., and Du, Z. J. (2017a). Aquimarina rubra sp. nov., isolated from sediment of a sea cucumber culture pond. Int. J. Syst. Evol. Microbiol. 67, 1932-1936. doi: 10.1099/ijsem.0.001889

Han, J. R., Geng, Q. L., Wang, F. Q., Du, Z. J., and Chen, G. J. (2017b). Algoriphagus marinus sp. nov., isolated from marine sediment and emended description of the genus Algoriphagus. Int. J. Syst. Evol. Microbiol. 67, 2412-2417. doi: 10.1099/ijsem.0.001971

Han, J. R., Zhao, J. X., Wang, Z. J., Chen, G. J., and Du, Z. J. (2017c). Algoriphagus resistens sp. nov., isolated from marine sediment. Int. J. Syst. Evol. Microbiol. 67, 1275-1280. doi: 10.1099/ijsem.0.001805

Kannan, L., and Wheeler, W. C. (2012). Maximum parsimony on phylogenetic networks. Algorithms. Mol. Biol. 7:9. doi: 10.1186/1748-7188-7-9

Khan, I. U., Hussain, F., Habib, N., Xiao, M., Ahmed, I., Amin, A., et al. (2017). Nocardioides thalensis sp. nov., isolated from a desert. Int. J. Syst. Evol. Microbiol. 67, 2848-2852. doi: 10.1099/ijsem.0.002032

Kim, O. S., Cho, Y. J., Lee, K., Yoon, S. H., Kim, M., Na, H., et al. (2012). Introducing EzTaxon-e: a prokaryotic 16S rRNA gene sequence database with phylotypes that represent uncultured species. Int. J. Syst. Evol. Microbiol. 62, 716-721. doi: 10.1099/ijs.0.038075-0

Kimura, M. (1980). A simple method for estimating evolutionary rates of base substitutions through comparative studies of nucleotide sequences. J. Mol. Evol. 16, 111-120. doi: 10.1007/BF01731581

Kumar, S., Stecher, G., and Tamura, K. (2016). MEGA7: molecular evolutionary genetics analysis version 7.0 for bigger datasets. Mol. Biol. Evol. 33, 1870-1874. doi: 10.1093/molbev/msw054

Lambert, C., Evans, K. J., Till, R., Hobley, L., Capeness, M., Rendulic, S., et al. (2006). Characterizing the flagellar filament and the role of motility in bacterial prey-penetration by Bdellovibrio bacteriovorus. Mol. Microbiol. 60, 274-286. doi: 10.1111/j.1365-2958.2006.05081.x

Liu, Q. Q., Wang, Y., Li, J., Du, Z. J., and Chen, G. J. (2014). Saccharicrinis carchari sp. nov., isolated from a shark, and emended descriptions of the genus Saccharicrinis and Saccharicrinis fermentans. Int. J. Syst. Evol. Microbiol. 64, 2204-2209. doi: 10.1099/ijs.0.061986-0

Lu, L., Cao, M., Wang, D., Yuan, K., Zhuang, W., Guo, W., et al. (2017). Nocardioides immobilis sp. nov., isolated from iron mine soil. Int. J. Syst. Evol. Microbiol. 67, 5230-5234. doi: 10.1099/ijsem.0.002450

Matson, J. A., and Bush, J. A. (1989). Sandramycin, a novel antitumor antibiotic produced by a Nocatdioides sp. Production, isolation, characterization and biological properties J. Antibiot. 42, 1763-1767. doi: 10.7164/antibiotics.42. 1763

Mendes-Soares, H., and Velicer, G. J. (2013). Decomposing predation: testing for parameters that correlate with predatory performance by a social bacterium. Micro. Ecol. 65, 415-423. doi: 10.1007/s00248-012-0135-6

Muñ;oz-Dorado, J., Marcos-Torres, F. J., García-Bravo, E., Moraleda-Muñoz, A., and Pérez, J. (2016). Myxobacteria: moving, killing, feeding, and surviving together. Front. Microbiol. 7:781. doi: 10.3389/fmicb.2016.00781

Mußmann, M., Pjevac, P., Krüger, K., and Dyksma, S. (2017). Genomic repertoire of the Woeseiaceae/JTB255, cosmopolitan and abundant core members of 
microbial communities in marine sediments. ISME J. 11, 1276-1281. doi: 10. 1038/ismej.2016.185

Na, S. I, Kim, Y. O., Yoon, S. H., Ha, S. M., Baek, I., and Chun, J. (2018). UBCG: up-to-date bacterial core gene set and pipeline for phylogenomic tree reconstruction. J. Microbiol. 56, 280-285. doi: 10.1007/s12275-018-8014-6

Ortiz-López, F. J., Alcalde, E., Sarmiento-Vizcaíno, A., Díaz, C., Cautain, B., García, L. A., et al. (2018). New 3-hydroxyquinaldic acid derivatives from cultures of the marine derived actinomycete Streptomyces cyaneofuscatus M-157. Marine Drugs 16:371. doi: 10.3390/md16100371

Pasternak, Z., Pietrokovski, S., Rotem, O., Gophna, U., Lurie-Weinberger, M. N., and Jurkevitch, E. (2013). By their genes ye shall know them: genomic signatures of predatory bacteria. ISME J. 7, 756-769. doi: 10.1038/ismej.2012.149

Pérez, J., Moraleda-Muñoz, A., Marcos-Torres, F. J., and Muñoz-Dorado, J. (2016). Bacterial predation: 75 years and counting!: bacterial predation. Environ. Microbiol. 18, 766-779. doi: 10.1111/1462-2920.13171

Rotem, O., Pasternak, Z., Shimoni, E., Belausov, E., Porat, Z., Pietrokovski, S., et al. (2015). Cell-cycle progress in obligate predatory bacteria is dependent upon sequential sensing of prey recognition and prey quality cues. Proc. Natl. Acad. Sci. U.S.A. 112, E6028-E6037. doi: 10.1073/pnas.1515749112

Saitou, M., and Nei, M. (1987). The neighbor-joining method: a new method for reconstructing phylogenetic trees. Mol. Biol. Evol. 4, 406-425.

Sockett, R. E. (2009). Predatory lifestyle of Bdellovibrio bacteriovorus. Annu. Rev. Microbiol. 63, 523-539. doi: 10.1146/annurev.micro.091208.073346

Soo, R. M., Woodcroft, B. J., Parks, D. H., Tyson, G. W., and Hugenholtz, P. (2015). Back from the dead; the curious tale of the predatory cyanobacterium Vampirovibrio chlorellavorus. PeerJ 3:e968. doi: 10.7717/peerj.968

Sun, H., Zusman, D. R., and Shi, W. Y. (2000). Type IV pilus of Myxococcus xanthus is a motility apparatus controlled by the frz chemosensory system. Curr. Biol. 10, 1143-1146. doi: 10.1016/s0960-9822(00)00705-3

Tang, B. L., Yang, J., Chen, X. L., Wang, P., Zhao, H. L., Su, H. N., et al. (2020). A predator-prey interaction between a marine Pseudoalteromonas sp. and Grampositive bacteria. Nat. Commun. 11:285. doi: 10.1038/s41467-019-14133-x

Tao, L., Yao, H., Kasai, H., Misawa, N., and Cheng, Q. (2006). A carotenoid synthesis gene cluster from Algoriphagus sp. KK10202C with a novel fusiontype lycopene $\beta$-cyclase gene. Mol. Gen. Genomics 276, 79-86. doi: 10.1007/ s00438-006-0121-0

Tindall, B. (1990). A comparative study of the lipid composition of Halobacterium saccharovorum from various sources. Syst. Appl. Microbiol. 13, 128-130. doi: 10.1016/s0723-2020(11)80158-x

Tindall, B. J. (1990). Lipid composition of Halobacterium lacusprofundi. FEMS Microbiol. Lett. 66, 199-202. doi: 10.1111/j.1574-6968.1990.tb03996.x

Uchino, Y., Hamada, T., and Yokota, A. (2002). Proposal of Pseudorhodobacter ferrugineus gen. nov., comb. nov., for a non-photosynthetic marine bacterium,
Agrobacterium ferrugineum, related to the genus Rhodobacter. J. Gen. Appl. Microbiol. 48, 309-319. doi: 10.2323/jgam.48.309

Wang, S., Mu, D. S., Zheng, W. S., and Du, Z. J. (2019). Complete genome sequence of Bradymonas sediminis FA350T, the first representative of the order Bradymonadales. Mar. Genomics 46, 62-65. doi: 10.1016/j.margen.2019.01.002

Wang, X., Jiang, W. K., Cui, M. D., Yang, Z. G., Yu, X., Hu, G., et al. (2017). Nocardioides agrisoli sp. nov., isolated from farmland soil. Int. J. Syst. Evol. Microbiol. 67, 3722-3727. doi: 10.1099/ijsem.0.002158

Wang, Z., Kadouri, D. E., and Wu, M. (2011). Genomic insights into an obligate epibiotic bacterial predator: Micavibrio aeruginosavorus ARL-13. BMC Genomics 12:453. doi: 10.1186/1471-2164-12-453

Wang, Z. J., Liu, Q. Q., Zhao, L. H., Du, Z. J., and Chen, G. J. (2015). Bradymonas sediminis gen. nov., sp. nov., isolated from coastal sediment, and description of Bradymonadaceae fam. nov. and Bradymonadales ord. nov. Int. J. Syst. Evol. Microbiol. 65, 1542-1549. doi: 10.1099/ijs.0.000135

$\mathrm{Xu}, \mathrm{X} . \mathrm{W} ., \mathrm{Wu}, \mathrm{Y} . \mathrm{H}$. , Wang, C. S., Oren, A., Zhou, P. J., and Wu, M. (2007). Haloferax larsenii sp. nov., an extremely halophilic archaeon from a solar saltern. Int. J. Syst. Evol. Microbiol. 57, 717-720. doi: 10.1099/ijs.0.64 573-0

Yoshikawa, T., Nakahara, M., Tabata, A., Kokumai, S., Furusawa, G., and Sakata, T. (2008). Characterization and expression of Saprospira cytoplasmic fibril protein (SCFP) gene from algicidal Saprospira spp. strains. Fish Sci. 74, 1109-1117. doi: 10.1111/j.1444-2906.2008.01630.x

Zhang, H. X., Wang, K., Xu, Z. X., Chen, G. J., and Du, Z. J. (2016). Nocardioides gilvus sp. nov., isolated from Namtso Lake. Antonie Van Leeuwenhoek 109, 1367-1374. doi: 10.1007/s10482-0160735-0

Zhang, W. P., Wang, Y., Song, Y. H., Wang, T. T., Xu, S. J., Peng, Z., et al. (2013). A type VI secretion system regulated by OmpR in Yersinia pseudotuberculosis functions to maintain intracellular $\mathrm{pH}$ homeostasis: role of T6SS in acid resistance. Environ. Microbiol. 15, 557-569. doi: 10.1111/1462-2920. 12005

Conflict of Interest: The authors declare that the research was conducted in the absence of any commercial or financial relationships that could be construed as a potential conflict of interest.

Copyright $(92020$ Wang, $M u$ and Du. This is an open-access article distributed under the terms of the Creative Commons Attribution License (CC BY). The use, distribution or reproduction in other forums is permitted, provided the original author(s) and the copyright owner(s) are credited and that the original publication in this journal is cited, in accordance with accepted academic practice. No use, distribution or reproduction is permitted which does not comply with these terms. 